\title{
A NON-STATIONARY GALE ECONOMY WITH LIMIT TECHNOLOGY, MULTILANE TURNPIKE AND GENERAL FORM OF OPTIMALITY CRITERION
}

\section{Abstract}

The paper refers to my previous works: “«Słaby» efekt magistrali w niestacjonarnej gospodarce Gale'a z graniczną technologią i wielopasmową magistralą produkcyjną” (in: Matematyka i informatyka na ustugach ekonomii, D. Appenzeller (ed.), 2017) and "Niestacjonarna gospodarka Gale'a z graniczną technologią i wielopasmową magistralą produkcyjną. «Słaby», «silny» i «bardzo silny» efekt magistrali" (Przeglad Statystyczny 2018, 65(4)), and contains proofs of weak and very strong turnpike theorems in a non-stationary Gale economy with limit technology and multilane turnpike. In contrast to the above-mentioned papers, the growth criterion is the maximization of discounted additive production utility over production in all periods of the economy's time horizon $T$.

Keywords: non-stationary Gale type economy, limit production space, discounted instantaneous utility, multilane turnpike.

JEL Classification: C6, O4.

\section{Introduction}

In many papers devoted to turnpike properties of optimal growth processes in von Neumann-Gale-Leontief type economies, maximization of

Emil Panek, Poznań University of Economics and Business, Faculty of Informatics and Electronic Economy, Department of Mathematical Economics, al. Niepodległości 10, 61-875 Poznań, Poland, e-mail: emil.panek@ue.poznan.pl, ORCID: https://orcid.org/0000-0002-7950-1689. 
the last period production utility in a planning horizon $T=\left(0,1, \ldots, t_{1}\right)^{1}$ is a growth criterion - so in these papers we have to do with the so-called final state optimization growth problem. Turnpike properties of optimal growth processes in stationary and non-stationary von Neumann-Gale type economies with maximization of total value of production over the whole planning horizon (measured at von Neumann prices) and a unique production turnpike have been discussed in papers by Panek \& Runka (2011, 2012) and Panek (2014, 2015).

The model we shall consider in the current paper is related to the model introduced in Panek $(2017,2018)$. The aim of the paper is to state and prove weak and strong turnpike theorems in a non-stationary Gale economy with limit technology and multilane turnpike with the sum of discounted production utilities serving as a growth criterion.

\section{The Model}

We are interested in a non-stationary economy with limit technology and multilane turnpike that has been presented in detail in the above-mentioned papers (Panek 2017, 2018), from which we also borrow the notation.

There are $n$ goods used and/or produced in periods $t=0,1, \ldots$ The symbol $x(t)=\left(x_{1}(t), \ldots, x_{n}(t)\right)$ denotes a vector of goods used in the economy (input vector) in period $t$, by $y(t)=\left(y_{1}(t), \ldots, y_{n}(t)\right)$ we mean a vector of goods produced (output vector) in period $t$. If from input vector $x(t)$ one can produce output vector $y(t)$ in period $t$, we say that the pair $(x(t), y(t))$ is (describes) a feasible production process in period $t$. By $Z(t) \subset R_{+}^{2 n}$ we denote the set of all feasible production processes in period $t$ and we call the set Gale's production space in period $t$. So, if $(x, y) \in Z(t)$ (or equivalently, $(x(t), y(t)) \in Z(t))$, then it is possible to produce output vector $y$ from input vector $x$ in period $t$.

Gale production (technology) spaces $Z(t), t=0,1, \ldots$, satisfy the following conditions $^{2}$ :

(G1) $\forall\left(x^{1}, y^{1}\right),\left(x^{2}, y^{2}\right) \in Z(t) \forall \lambda_{1}, \lambda_{2} \geq 0\left(\lambda_{1}\left(x^{1}, y^{1}\right)+\lambda_{2}\left(x^{2}, y^{2}\right) \in Z(t)\right)$ (homogeneity and additivity of production processes).

\footnotetext{
${ }^{1}$ Utility is usually identified with a value of a continuous, positively homogeneous of degree one, and concave function $u: R_{+}^{n} \rightarrow R_{+}^{1}$, of which a particular example is the linear functional measuring value of the last period $T$ production measured at equilibrium (von Neumann) prices, see Lancaster (1968, Ch. 10-11), McKenzie (2005), Nikaido (1968, Ch. 4.12-13), Panek (2011), Takayama (1985, Ch. 7A) and references therein.

${ }^{2} x \geqq 0$ means that $\forall i\left(x_{i} \geq 0\right)$, in contrast to $x \geq 0$ which means $(x \geqq 0 \wedge x \neq 0)$.
} 
(G2) $\forall(x, y) \in Z(t)(x=0 \Rightarrow y=0)$

(no land-of-Cockaigne condition).

(G3) $\forall(x, y) \in Z(t) \forall x^{\prime} \geqq x \forall 0 \leqq y^{\prime} \leqq y\left(\left(x^{\prime}, y^{\prime}\right) \in Z(t)\right)$

(costless waste condition).

(G4) $Z(t)$ is a closed subset of $R_{+}^{2 n}$.

(G5) $Z(0) \neq \varnothing$ and $Z(t) \subseteq Z(t+1)$.

We also assume that there exists the smallest (in the sense of inclusion) closed set $Z \subseteq R_{+}^{2 n}$, called the limit production (technology) space, which satisfies the conditions:

(G6) (i) $Z(t) \subseteq Z, t=0,1, \ldots$

(ii) $(x, y) \in Z$ and $x=0$, imply $y=0$.

(iii) $\forall i \exists\left(x^{i}, y^{i}\right) \in Z\left(y_{i}^{i}>0\right)$.

(each good can be produced under the limit technology).

It is not difficult to demonstrate that the set $Z \subset R_{+}^{2 n}$ satisfies conditions (G1)-(G4) (Panek 2016b, Th. 1). Moreover, sets $Z, Z(t), t=0,1, \ldots$, are closed convex cones in $R^{2 n}$ with vertices at $0 \in R^{2 n}$. Let us observe that assumptions (G6)(ii)-(iii), due to the fact that the limit technology space is the smallest set, implicitly impose some additional conditions on almost all production sets $Z(t), t=0,1, \ldots$. Writing $(x, y) \in Z$ means that it is possible to produce output vector $y$ from input vector $x$ in view of the limit technology. An economy with production space meeting conditions (G1)-(G6) is called a non-stationary Gale economy with limit technology.

If $(x, y) \in Z(t)$ and $(x, y) \neq 0$, then (by (G2)) $x \neq 0$ and we define:

$$
\alpha(x, y)=\max \{\alpha \mid \alpha x \leqq y\},
$$

and call it the technological efficiency rate of the (feasible) production process $(x, y)$ in period $t$. We similarly define the technological efficiency rate of a non-trivial feasible limit production process $(x, y) \in Z$. Under assumptions (G1)-(G6) the function $\alpha(\cdot)$ defined on $Z \backslash\{0\}$ is positively homogeneous of degree zero and there exists a process $(\bar{x}, \bar{y}) \in Z \backslash\{0\}$ for which (Takayama 1985, Th. 6.A.1):

$$
\alpha(\bar{x}, \bar{y})=\max _{(x, y) \in Z \backslash\{0\}} \alpha(x, y)=\alpha_{M}>0 .
$$

We call every such process an optimal production process in a non-stationary Gale economy with limit technology. The number $\alpha_{M}$ is said to 
be the optimal (limit) technological efficiency rate. Let us observe that any positive multiple of an optimal process $(\bar{x}, \bar{y})$ is also an optimal process.

From now on we consider only non-trivial (non-zero) production processes belonging to $Z(t), t=0,1, \ldots$, or to $Z$.

By $Z_{\text {opt }}$ we denote the set of all optimal processes in a non-stationary Gale economy with limit technology:

$$
Z_{\text {opt }}=\left\{(\bar{x}, \bar{y}) \in Z \backslash\{0\} \mid \alpha(\bar{x}, \bar{y})=\alpha_{M}>0\right\} .
$$

If conditions (G1)-(G6) hold, then (Panek 2016a, Th. 1):

- the set $Z_{\text {opt }}$ is a convex cone not containing 0 ,

$-\forall(\bar{x}, \bar{y}) \in Z_{\text {opt }}(\bar{x} \geq 0 \wedge \bar{y} \geq 0)$,

$-\forall(\bar{x}, \bar{y}) \in Z_{\text {opt }}\left(\left(\bar{x}, \alpha_{M} \bar{x}\right) \in Z_{\text {opt }} \wedge\left(\bar{y}, \alpha_{M} \bar{y}\right) \in Z_{\text {opt }}\right)$.

Let us introduce the following notation ${ }^{3}$ :

$$
S=\left\{s \in R_{+}^{n} \mid \exists(\bar{x}, \bar{y}) \in Z_{\text {opt }}\left(s=\frac{\bar{y}}{\|\bar{y}\|}\right)\right\}
$$

(the set of production structures $s=\frac{\bar{y}}{\|\bar{y}\|}$ of optimal production processes $\left.(\bar{x}, \bar{y}) \in Z_{\text {opt }}\right)$. It can be shown that the set $S$ is non-empty, convex and compact (Panek 2016a, Th. 2(i)). For any $s \in S$, the half-line

$$
N_{s}=\{\lambda s \mid \lambda>0\}
$$

is called a von Neumann ray (production turnpike) in a non-stationary Gale economy with limit technology. The set (bundle of turnpikes)

$$
\mathbb{N}=\cup_{s \in S} N_{s}
$$

is called the multilane turnpike in a (non-stationary) Gale economy with limit technology.

By $p=\left(p_{1}, \ldots, p_{n}\right) \geq 0$ we denote a price vector of goods. For $(x, y) \in Z \backslash\{0\}$, the number 4 :

$$
\beta(x, y, p)=\frac{\langle p, y\rangle}{\langle p, x\rangle} \geq 0 \quad(\text { defined if }\langle p, x\rangle \neq 0)
$$

${ }^{3}$ From here onwards: if $a \in R_{+}^{n}$, then $\|a\|=\sum_{i=1}^{n} a_{i}$.
${ }^{4}$ For $a, b \in R^{n},\langle a, b\rangle=\sum_{i=1}^{n} a_{i} b_{i}$. 
is called the economic efficiency rate of the process $(x, y)$ at prices $p$. If there exist a price vector $\bar{p} \geq 0$ and a production process $(\bar{x}, \bar{y}) \in Z \backslash\{0\}$ such that:

$$
\begin{gathered}
\alpha_{M} \bar{x} \leqq \bar{y}, \\
\forall(x, y) \in Z \backslash\{0\}\left(\langle\bar{p}, y\rangle \leq \alpha_{M}\langle\bar{p}, x\rangle\right), \\
\langle\bar{p}, \bar{y}\rangle>0,
\end{gathered}
$$

then the triplet $\left\{\alpha_{M},(\bar{x}, \bar{y}), \bar{p}\right\}$ is said to characterize (describe) an optimal von Neumann equilibrium in a non-stationary Gale economy with limit technology. The vector $\bar{p}$ is called a von Neumann price vector (or equilibrium price vector). Let us remark that the state of equilibrium is such a state of economy (production and price levels) in which the economic efficiency rate equals the technological efficiency rate at the highest possible level. This is due to the fact that by (1)-(3) we obtain:

$$
\beta(\bar{x}, \bar{y}, \bar{p})=\max _{(x, y) \in Z \backslash\{0\}} \beta(x, y, \bar{p})=\alpha(\bar{x}, \bar{y})=\alpha_{M}>0 .
$$

The condition (1) is satisfied by any optimal production process $(\bar{x}, \bar{y}) \in Z_{\text {opt }}$. Further, for a non-stationary Gale economy with limit technology there exists a price vector $\bar{p} \geq 0$ fulfilling condition (2). By (4) it follows that the economic efficiency rate of an arbitrary process $(x, y) \in Z \backslash\{0\}$ never exceeds the optimal technological efficiency rate $\alpha_{M}$.

The next condition (G7) states that if the technological efficiency rate of some production process is less than the optimal rate, then its economic efficiency (measured at von Neumann prices $\bar{p}$ ) is less than the optimal rate as well. In other words, any production process not attaining the maximum technological efficiency rate cannot attain the maximum economic efficiency rate:

(G7) $\forall(x, y) \in Z \backslash\{0\}\left(\alpha(x, y)<\alpha_{M} \Rightarrow \beta(x, y, \bar{p})<\alpha_{M}\right)$.

Under condition (G7), every process $(\bar{x}, \bar{y}) \in Z_{\text {opt }}$ and price vector $\bar{p}$ is a state of von Neumann, that is, it meets conditions (1)-(3) (see Panek 2018, Th. 1) and, moreover,

$$
\forall \varepsilon>0 \exists \delta_{\varepsilon} \in\left(0, \alpha_{M}\right) \forall(x, y) \in Z \backslash\{0\}\left(d(x, \mathbb{N}) \geq \varepsilon \Rightarrow \beta(x, y, \bar{p}) \leq \alpha_{M}-\delta_{\varepsilon}\right),
$$

where

$$
d(x, \mathbb{N})=\inf _{x^{\prime} \in \mathbb{N}}\left\|\frac{x}{\|x\|}-\frac{x^{\prime}}{\left\|x^{\prime}\right\|}\right\|
$$


is the (angular) distance of the vector from the multilane turnpike $\mathbb{N}$ (Panek 2017, Th. 5) $)^{5}$.

Let us now fix a process $(x, y) \in Z \backslash\{0\}$ whose input structure $\frac{x}{\|x\|}$ or output structure $\frac{y}{\|y\|}$ differ from any turnpike structure:

$$
\frac{x}{\|x\|} \notin S \vee \frac{y}{\|y\|} \notin S
$$

or, equivalently,

$$
x \notin \mathbb{N} \vee y \notin \mathbb{N} .
$$

Hence, under the conditions (G1)-(G6), the technological efficiency rate of such a process is less than the optimal rate (Panek 2018, Lemma 1):

$$
\alpha(x, y)<\alpha_{M} .
$$

By this and the condition (G7) we conclude that if, in a production process $(x, y) \in Z \backslash\{0\}$, input vector $x$ or output vector $y$ do not belong to the multilane turnpike $\mathbb{N}$, the economic efficiency rate measured at some von Neumann price vector is less than the maximum efficiency rate.

\section{Weak Multilane Turnpike Theorem}

We are interested in a Gale economy satisfying conditions (G1)-(G7) and functioning within a (finite) time horizon $T=\left\{0,1, \ldots, t_{1}\right\}, t_{1}<+\infty$. Production dynamics obey the following simple condition:

$$
x(t+1) \leqq y(t), \quad t=0,1, \ldots, t_{1}-1,
$$

according to which a period's inputs stem from goods produced in the previous period $^{6}$. For this reason and by the condition (G3) we get:

$$
(y(t), y(t+1)) \in Z(t+1), \quad t=0,1, \ldots, t_{1}-1 .
$$

We assume that in the initial period $t=0$ a production vector $y(0)$ is given:

$$
y(0)=y^{0}>0 .
$$

Every sequence $\{y(t)\}_{t=0}^{t_{1}}$ satisfying conditions (6)-(7) is called a (feasible) $\left(y^{0}, t_{1}\right)$ - growth process (production trajectory). In the papers by Panek

\footnotetext{
${ }^{5}$ It is a version of Radner's Lemma adapted to our model (Radner 1961).

${ }^{6}$ By this we mean a closed economy.
} 
(2017, 2018), we investigated the properties of feasible growth processes and solved the following final state optimization problem (utility maximization of production obtained in the last period $t_{1}$ in horizon $T$ ):

$$
\begin{gathered}
\max u\left(y\left(t_{1}\right)\right) \\
\text { subject to }(6)-(7) \\
\text { with fixed } y^{0} .
\end{gathered}
$$

In the present work, we replace the final state optimization criterion (8) with the criterion of maximization of total discounted utility of production obtained in all periods of the horizon $T$ :

$$
\begin{gathered}
\max \sum_{t \in T}(1-\gamma)^{t} u(y(t)) \\
\text { subject to (6)-(7) } \\
\text { with fixed } y^{0} .
\end{gathered}
$$

The instantaneous utility function $u: R_{+}^{n} \rightarrow R_{+}^{1}$ is assumed to satisfy the following conditions:

(U1) $u(\cdot)$ is continuous, positively homogeneous of degree 1 , concave and increasing,

(U2) $\exists a>0 \forall y \in R_{+}^{n}(u(y) \leq a\langle\bar{p}, y\rangle)$,

(U3) $\forall s \in S(u(s)>0)$.

Such conditions are satisfied e.g. by some functions of the CES class. Parameter $\gamma \in(0,1)$ is a discount rate (time preference) of production utility. Under the above assumptions, $\forall y^{0}>0 \forall t_{1}<+\infty$ problem (9) possesses an optimal solution which will be denoted by $\left\{y^{*}(t)\right\}_{t=0}^{t_{1}}$ and called an $\left(y^{0}, T, u\right)-$ optimal growth process (production trajectory).

While proving the weak turnpike effect (Theorem 1), we will need the following condition which guarantees that it is possible to attain the multilane production turnpike starting from the initial state $y^{0}$ :

(G8) There exists a feasible $\left(y^{0}, \check{t}+1\right)$ - growth process $\left\{\check{y}(t)_{t=0}^{\check{t}+1}, \check{t}<t_{1}\right.$, such that

$$
\alpha(\breve{y}(\check{t}), \check{y}(\check{t}+1))=\alpha_{M} .
$$

Let us discuss the economic meaning of (G8). To this end, we denote: $\check{y}=\check{y}(\check{t}), \check{s}=\frac{\check{y}}{\|\check{y}\|}$. If $(\mathrm{G} 8)$ holds, then $\left(\check{y}, \alpha_{M} \check{y}\right) \in Z(t+1) \subseteq Z$ and thus $\left(\check{y}, \alpha_{M} \check{y}\right) \in Z_{\text {opt }}$, so: 


$$
\check{y}(\check{t}) \in N_{\check{s}} \in \mathbb{N},
$$

where the half-line $N_{\check{s}}=\{\lambda \check{s} \mid \lambda>0\}$ is a von Neumann ray determined by the production structure vector $\breve{s}$ in the optimal process $\left(\breve{y}, \alpha_{M} \breve{y}\right) \in Z_{\text {opt }}$, and

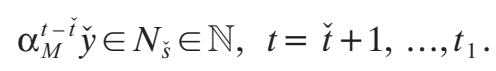

Thus, condition (G8) entails that the economy, after having reached the multilane turnpike $\mathbb{N}$ (one of the rays), can continue its growth by staying on the turnpike and growing at the rate $\alpha_{M}$. This growth rate is the optimal (highest attainable) production growth rate in a Gale economy, which accounts for calling the processes of the form (10) the optimal stationary growth processes in the literature. These optimal processes stay on the multilane turnpike $\mathbb{N}$.

Theorem 1. In a non-stationary Gale economy satisfying conditions (G1)-(G8), if the discounted optimal production growth rate $(1-\gamma) \alpha_{M}$ exceeds 1 , then for any $\varepsilon>0$ there exists a positive integer $k_{\varepsilon}$ for which the number of periods in which the production structure of a $\left(y^{0}, T, u\right)$ - optimal process $\left\{y^{*}(t)\right\}_{t=0}^{t_{1}}$ satisfies the condition:

$$
d\left(y^{*}(t), \mathbb{N}\right)=\inf _{y \in \mathbb{N}}\left\|\frac{y^{*}(t)}{\left\|y^{*}(t)\right\|}-\frac{y}{\|y\|}\right\|=d\left(y^{*}(t), \mathbb{N}\right) \geq \varepsilon
$$

is not greater than $k_{\varepsilon}$. The number $k_{\varepsilon}$ is independent of the horizon $T$ length.

Proof. We will use the fact that problem (9) is equivalent to

$$
\begin{gathered}
\max \sum_{t=1}^{t_{1}}(1-\gamma)^{t} u(y(t)) \\
\text { subject to (6)-(7) } \\
\text { with fixed } y^{0}
\end{gathered}
$$

(a trajectory $\left\{y^{*}(t)\right\}_{t=0}^{t_{1}}$ solves the problem (9) if and only if it solves (12)). According to (G6), (2), (6), we have

$$
\begin{aligned}
& \left\langle\bar{p}, y^{*}(1)\right\rangle \leq \alpha_{M}\left\langle\bar{p}, y^{0}\right\rangle, \\
& \left\langle\bar{p}, y^{*}(2)\right\rangle \leq \alpha_{M}\left\langle\bar{p}, y^{*}(1)\right\rangle \leq \alpha_{M}^{2}\left\langle\bar{p}, y^{0}\right\rangle, \\
& \ldots \ldots \ldots . . \\
& \left\langle\bar{p}, y^{*}\left(t_{1}\right)\right\rangle \leq \alpha_{M}\left\langle\bar{p}, y^{*}\left(t_{1}-1\right)\right\rangle \leq \alpha_{M}^{t_{1}}\left\langle\bar{p}, y^{0}\right\rangle .
\end{aligned}
$$


Assume that in some periods $0 \leq \tau_{1}, \tau_{2}, \ldots, \tau_{k}<\tau_{1}$ the condition (11) is fulfilled. Then, by (5),

$$
\beta\left(y^{*}(t), y^{*}(t+1)\right) \leq \alpha_{M}-\delta_{\varepsilon}, \quad t=\tau_{1}, \ldots, \tau_{k},
$$

or, equivalently,

$$
\left\langle\bar{p}, y^{*}(t+1)\right\rangle \leq\left(\alpha_{M}-\delta_{\varepsilon}\right)\left\langle\bar{p}, y^{*}(t)\right\rangle, \quad t=\tau_{1}, \ldots, \tau_{k},
$$

where $\delta_{\varepsilon} \in\left(0, \alpha_{M}\right)$. From (U2), (13), (14) we obtain

$$
\begin{aligned}
& (1-\gamma) u\left(y^{*}(1)\right) \leq a(1-\gamma)\left\langle\bar{p}, y^{*}(1)\right\rangle \leq a(1-\gamma) \alpha_{M}\left\langle\bar{p}, y^{0}\right\rangle, \\
& (1-\gamma)^{2} u\left(y^{*}(2)\right) \leq a(1-\gamma)^{2}\left\langle\bar{p}, y^{*}(2)\right\rangle \leq a(1-\gamma)^{2} \alpha_{M}^{2}\left\langle\bar{p}, y^{0}\right\rangle,
\end{aligned}
$$

$$
\begin{aligned}
& (1-\gamma)^{t_{1}-k} u\left(y^{*}\left(t_{1}-k\right)\right) \leq a(1-\gamma)^{t_{1}-k}\left\langle\bar{p}, y^{*}\left(t_{1}-k\right)\right\rangle \leq a(1-\gamma)^{t_{1}-k} \alpha_{M}^{t_{1}-k}\left\langle\bar{p}, y^{0}\right\rangle \\
& (1-\gamma)^{t_{1}-k+1} u\left(y^{*}\left(t_{1}-k+1\right)\right) \leq a(1-\gamma)^{t_{1}-k+1}\left\langle\bar{p}, y^{*}\left(t_{1}-k+1\right)\right\rangle \leq \\
& \quad \leq a(1-\gamma)^{t_{1}-k+1} \alpha_{M}^{t_{1}-k}\left(\alpha_{M}-\delta_{\varepsilon}\left\langle\bar{p}, y^{0}\right\rangle\right.
\end{aligned}
$$

$(1-\gamma)^{t_{1}} u\left(y^{*}\left(t_{1}\right)\right) \leq a(1-\gamma)^{t_{1}}\left\langle\bar{p}, y^{*}\left(t_{1}\right)\right\rangle \leq a(1-\gamma)^{t_{1}} \alpha_{M}^{t_{1}-k}\left(\alpha_{M}-\delta_{\varepsilon}\right)^{k}\left\langle\bar{p}, y^{0}\right\rangle$, and finally we get

$$
\begin{gathered}
\sum_{t=1}^{t_{1}}(1-\gamma)^{t} u\left(y^{*}(t)\right) \leq \\
\leq a\left\langle\bar{p}, y^{0}\right\rangle\left[\sum_{t=1}^{t_{1}-k}(1-\gamma)^{t} \alpha_{M}^{t}+(1-\gamma)^{t_{1}-k} \alpha_{M}^{t_{1}-k} \sum_{\tau=1}^{k}(1-\gamma)^{\tau}\left(\alpha_{M}-\delta_{\varepsilon}\right)^{\tau}\right] .
\end{gathered}
$$

On the other hand, due to (G8), the process $\{\tilde{y}(t)\}_{t=0}^{t_{1}}$ defined by

$$
\tilde{y}(t)=\left\{\begin{array}{l}
\{\check{y}(t), t=0,1, \ldots, \check{t} . \\
\sigma \check{s} \alpha_{M}^{t-\check{t}}, t=\check{t}+1, \ldots, t_{1}
\end{array}\right.
$$

$\left(\check{s}=\frac{\check{y}(\check{t})}{\|\check{y}(\check{t})\|} \in S, \sigma=\|\check{y}(\check{t})\|>0\right)$ is $\left(y^{0}, t_{1}\right)$ - feasible, and in view of (12), we have

$$
\begin{aligned}
\sum_{t=1}^{t_{1}}(1-\gamma)^{t} u\left(y^{*}(t)\right) & \geq \sum_{t=1}^{t_{1}}(1-\gamma)^{t} u(\tilde{y}(t)) \geq \sigma \sum_{t=\check{t}+1}^{t_{1}}(1-\gamma)^{t-\breve{t}} u(\breve{s})= \\
& =\sigma u(\check{s}) \sum_{\tau=1}^{t_{1-1}}(1-\gamma)^{\tau}>0 .
\end{aligned}
$$


By (15), (16) we have

$$
\begin{gathered}
a\left\langle\bar{p}, y^{0}\right\rangle\left[\sum_{\tau=1}^{t_{1}-k}(1-\gamma)^{\tau} \alpha_{M}^{\tau}+(1-\gamma)^{t_{1}-k} \alpha_{M}^{t_{1}-k} \sum_{\tau=1}^{k}(1-\gamma)^{\tau}\left(\alpha_{M}-\delta_{\varepsilon}\right)^{\tau}\right] \geq \\
\geq \sigma u(\check{s}) \sum_{\tau=1}^{t_{1-\bar{t}}}(1-\gamma)^{\tau}>0,
\end{gathered}
$$

and

$$
\begin{gathered}
\sum_{\tau=1}^{t_{1}-k}(1-\gamma)^{\tau} \alpha_{M}^{\tau}+(1-\gamma)^{t_{1}-k} \alpha_{M}^{t_{1}-k} \sum_{\tau=1}^{k}(1-\gamma)^{\tau}\left(\alpha_{M}-\delta_{\varepsilon}\right)^{\tau} \geq \\
\geq \frac{\sigma u(\check{s})}{a\left\langle\bar{p}, y^{0}\right\rangle} \sum_{\tau=1}^{t_{1}-\check{t}}(1-\gamma)^{\tau}>0
\end{gathered}
$$

or, equivalently,

$$
\begin{gathered}
(1-\gamma) \alpha_{M} \frac{(1-\gamma)^{t_{1}-k} \alpha_{M}^{t_{1}-k}-1}{(1-\gamma) \alpha_{M}-1}+(1-\gamma)^{t_{1}-k+1} \alpha_{M}^{t_{1}-k}\left(\alpha_{M}-\delta_{\varepsilon}\right) \frac{(1-\gamma)^{k}\left(\alpha_{M}-\delta_{\varepsilon}\right)^{k}-1}{(1-\gamma)\left(\alpha_{M}-\delta_{\varepsilon}\right)-1} \geq \\
\geq \frac{\sigma u(\breve{s})}{a\left\langle\bar{p}, y^{0}\right\rangle}(1-\gamma) \alpha_{M} \frac{(1-\gamma)^{t_{1}-\check{t}} \alpha_{M}^{t_{1}-\breve{t}}-1}{(1-\gamma) \alpha_{M}-1}>0 .
\end{gathered}
$$

Taking $\delta_{\varepsilon} \in\left(0, \alpha_{M}\right)$ such that $\left(\alpha_{M}-\gamma\right)\left(1-\delta_{\varepsilon}\right)>1$, after simple transformations we get

$$
\forall t_{1}<+\infty \forall k \leq t_{1}\left(A\left(t_{1}, k\right)+B\left(t_{1}, k\right) \geq C=\frac{\sigma u(\check{s})}{a\left\langle\bar{p}, y^{0}\right\rangle}>0\right),
$$

where

$$
\begin{gathered}
A\left(t_{1}, k\right)=\frac{(1-\gamma)^{t_{1}-k} \alpha_{M}^{t_{1}-k}-1}{(1-\gamma)^{t_{1}-\grave{t}} \alpha_{M}^{t_{1}-\grave{t}}-1}, \\
B\left(t_{1}, k\right)=\frac{(1-\gamma)^{t_{1}-k} \alpha_{M}^{t_{1}-k-1}\left(\alpha_{M}-\delta_{\varepsilon}\right)\left[(1-\gamma)^{k}\left(\alpha_{M}-\delta_{\varepsilon}\right)^{k}-1\right]\left[(1-\gamma) \alpha_{M}-1\right]}{\left[(1-\gamma)^{t_{1}-\breve{t}} \alpha_{M}^{t_{1}-\breve{t}}-1\right]\left[(1-\gamma)\left(\alpha_{M}-\delta_{\varepsilon}\right)-1\right]} .
\end{gathered}
$$

But for $k \rightarrow+\infty\left(t_{1} \geq k\right)$ :

$$
A\left(t_{1}, k\right) \rightarrow 0^{+} \text {and } B\left(t_{1}, k\right) \rightarrow 0^{+},
$$

which contradicts (17). Hence, there exists a positive integer $k_{\varepsilon}$ (independent of $t_{1}$ ) such that the number of periods for which (11) holds is not greater than $k_{\varepsilon}$. 
If a Gale economy satisfies conditions (G1)-(G8), then, independently of the horizon $T$ length, the production structure in any $\left(y^{0}, T, u\right)$ - optimal process (solution of (9)) differs arbitrarily from a production structure on the multilane turnpike. The economy achieves its highest growth rate on the turnpike.

\section{Very Strong Multilane Turnpike Theorem}

In this section, we have to do with a special situation when there is a $\left(y^{0}, T, u\right)$ - optimal process $\left\{y^{*}(t)\right\}_{t=0}^{t_{1}}$ which reaches the multilane turnpike $\mathbb{N}$ at some period $\check{t}<t_{1}$, and if property (U2) of the instantaneous utility function changes to

(U2') $\exists a>0 \forall s \in S(u(y)=a\langle\bar{p}, y\rangle)^{7}$.

Under the just mentioned conditions we have:

$\square$ Theorem 2. Under conditions (G1)-(G7) and (U1), (U2') and if a $\left(y^{0}, T, u\right)$ - optimal process $\left\{y^{*}(t)\right\}_{t=0}^{t_{1}}$, for some $\check{t}<t_{1}$, reaches the multilane turnpike $\mathbb{N}$, that is, it meets the condition

$$
\alpha\left(y^{*}(t), y^{*}(t+1)\right)=\alpha_{M},
$$

then

$$
\forall t \in\left\{\check{t}+1, \ldots, t_{1}-1\right\}\left(y^{*}(t) \in \mathbb{N}\right) .
$$

Proof $^{8}$. If the $\left(y^{0}, T, u\right)-$ optimal process $\left\{y^{*}(t)\right\}_{t=0}^{t_{1}}$ satisfies (18), then the process $\{\tilde{y}(t)\}_{t=0}^{t_{1}}$ defined by

$$
\tilde{y}(t)=\left\{\begin{array}{l}
y^{*}(t), t=0,1, \ldots, \check{t} \\
\sigma s^{*} \alpha_{M}^{t-\grave{t}}, t=\check{t}+1, \ldots, t_{1},
\end{array}\right.
$$

where $\sigma=\left\|y^{*}(\check{t})\right\|>0, s^{*}=\frac{y^{*}(\check{t})}{\left\|y^{*}(\check{t})\right\|}$, is a feasible $\left(y^{0}, t_{1}\right)$ - growth process. Since, for $t=0,1, \ldots, \check{t}, \tilde{y}(t)=y^{*}(t)$,

$$
\sum_{t=\check{t}}^{t_{1}}(1-\gamma)^{t} u\left(y^{*}(t)\right) \geq \sum_{t=\check{t}}^{t_{1}}(1-\gamma)^{t} u(\tilde{y}(t))=\sigma u\left(s^{*}\right) \sum_{t=\check{t}}^{t_{1}}(1-\gamma)^{t} \alpha_{M}^{t-\check{t}}>0 .
$$

${ }^{7}$ A linear form with the vector of cofficients ap approximating the function $u(\cdot)$ from above is tangent to the graph of $u(\cdot)$ along the multilane turnpike $\mathbb{N}$.

${ }^{8}$ The condition (G8) is redundant in the proof, since the optimal process $\left\{y^{*}(t)\right\}_{t=0}^{t_{1}}$ meets this condition by formula (18). 
But, by the conditions (G6), (2) (6), it holds

$$
\begin{aligned}
& \left\langle\bar{p}, y^{*}(\check{t})\right\rangle=\sigma\left\langle\bar{p}, s^{*}\right\rangle, \\
& \left\langle\bar{p}, y^{*}(\check{t}+1)\right\rangle \leq \sigma \alpha_{M}\left\langle\bar{p}, s^{*}\right\rangle, \\
& \ldots \ldots \ldots \ldots . . \\
& \left\langle\bar{p}, y^{*}\left(t_{1}\right)\right\rangle \leq \sigma \alpha_{M} \alpha_{M}^{t_{1}-\check{t}}\left\langle\bar{p}, s^{*}\right\rangle .
\end{aligned}
$$

Suppose that for some $\tau \in\left\{\check{t}+1, \ldots, t_{1}-1\right\}$ :

$$
\left(y^{*}(\tau) \notin \mathbb{N}\right),
$$

that is, $\exists \varepsilon>0\left(d\left(y^{*}(\tau), \mathbb{N}\right) \geq \varepsilon\right)$. Then, according to (5), there is $\delta_{\varepsilon} \in\left(0, \alpha_{M}\right)$ for which

$$
\left\langle\bar{p}, y^{*}(\tau+1)\right\rangle \leq\left(\alpha_{M}-\delta_{\varepsilon}\right)\left\langle\bar{p}, y^{*}(\tau)\right\rangle \text {. }
$$

By conditions (20) and (21), in view of (U2'), we obtain:

$$
\begin{aligned}
& (1-\gamma)^{\check{t}} u\left(y^{*}(\check{t})\right) \leq a(1-\gamma)^{\check{t}}\left\langle\bar{p}, y^{*}(\check{t})\right\rangle=\sigma a(1-\gamma)^{\check{t}}\left\langle\bar{p}, s^{*}\right\rangle=\sigma(1-\gamma)^{\check{t}} u\left(s^{*}\right), \\
& (1-\gamma)^{\check{t}+1} u\left(y^{*}(\check{t}+1)\right) \leq a(1-\gamma)^{\check{t}+1}\left\langle\bar{p}, y^{*}(\check{t}+1)\right\rangle \leq \sigma a(1-\gamma)^{\check{t}+1} \alpha_{M}\left\langle\bar{p}, s^{*}\right\rangle= \\
& \quad=\sigma(1-\gamma)^{\check{t}+1} \alpha_{M} u\left(s^{*}\right),
\end{aligned}
$$

$$
\begin{aligned}
& (1-\gamma)^{\tau} u\left(y^{*}(\tau)\right) \leq a(1-\gamma)^{\tau}\left\langle\bar{p}, y^{*}(\tau)\right\rangle \leq \sigma a(1-\gamma)^{\tau} \alpha_{M}^{\tau-\check{t}}\left\langle\bar{p}, s^{*}\right\rangle= \\
& \quad=\sigma(1-\gamma)^{\tau} \alpha_{M}^{\tau-\check{t}} u\left(s^{*}\right), \\
& (1-\gamma)^{\tau+1} u\left(y^{*}(\tau+1)\right) \leq \alpha(1-\gamma)^{\tau+1}\left\langle\bar{p}, y^{*}(\tau+1)\right\rangle \leq \\
& \quad \leq \sigma a(1-\gamma)^{\tau+1} \alpha_{M}^{\tau-\check{t}}\left(\alpha_{M}-\delta_{\varepsilon}\right)\left\langle\bar{p}, s^{*}\right\rangle=\sigma(1-\gamma)^{\tau+1} \alpha_{M}^{\tau-\check{t}}\left(\alpha_{M}-\delta_{\varepsilon}\right) u\left(s^{*}\right),
\end{aligned}
$$

$$
\begin{aligned}
& (1-\gamma)^{t_{1}} u\left(y^{*}\left(t_{1}\right)\right) \leq a(1-\gamma)^{t_{1}}\left\langle\bar{p}, y^{*}\left(t_{1}\right)\right\rangle \leq \sigma a(1-\gamma)^{t_{1}} \alpha_{M}^{t_{1}-\check{t}-1}\left(\alpha_{M}-\delta_{\varepsilon}\right)\left\langle\bar{p}, s^{*}\right\rangle= \\
& =\sigma(1-\gamma)^{t_{1}} \alpha_{M}^{t_{1}-\check{t}-1}\left(\alpha_{M}-\delta_{\varepsilon}\right) u\left(s^{*}\right),
\end{aligned}
$$

which leads to

$$
\begin{gathered}
\sum_{t=\check{t}}^{t_{1}}(1-\gamma)^{t} u\left(y^{*}(t)\right) \leq \\
\leq \sigma u\left(s^{*}\right)\left[\sum_{t=\check{t}}^{t_{1}}(1-\gamma)^{t} \alpha_{M}^{t-\check{t}}-\delta_{\varepsilon} \sum_{t=\tau}^{t_{1}-1}(1-\gamma)^{t+1} \alpha_{M}^{t-\check{t}}\right] .
\end{gathered}
$$


By (19) and (22) we see that

$$
\begin{gathered}
\sigma u\left(s^{*}\right)\left[\sum_{t=\check{t}}^{t_{1}}(1-\gamma)^{t} \alpha_{M}^{t-\check{t}}-\delta_{\varepsilon} \sum_{t=\tau}^{t_{1}-1}(1-\gamma)^{t+1} \alpha_{M}^{t-\check{t}}\right] \geq \\
\geq \sigma u\left(s^{*}\right) \sum_{t=\check{t}}^{t_{1}}(1-\gamma)^{t} \alpha_{M}^{t-\check{t}}>0 .
\end{gathered}
$$

Hence, $\delta_{\varepsilon} \leq 0$. This contradiction ends the proof.

Let us note the above proof does not require the discounted optimal growth rate to be greater than 1 .

\section{Final Remarks}

Obviously, Theorems 1 and 2 remain true for a stationary Gale economy with multilane turnpike and time-invariant production space, that is, when $\forall t(Z(t)=Z=$ const $)$. In this case, in Theorem 1 , as well as in Theorem 2 (but for some other reason), condition (G8) becomes redundant. It easy to show that if the initial production vector $y^{0}$ is positive (see (7)) and production technology is constant in time, then condition (G8) is satisfied with $\check{t}=1$.

An interesting, but much more difficult, research problem would be to investigate turnpike properties of optimal growth processes in non-stationary von Neumann-Gale type economies with multilane turnpike without assuming the existence of limit technology space. The hypothesis that there exists a limit technology might cause some controversy, and it is certainly not a testable restriction imposed on the economy.

\section{Bibliography}

Lancaster, K. (1968) Mathematical Economics. New York: Macmillan.

McKenzie, L. W. (2005) "Optimal Economic Growth, Turnpike Theorems and Comparative Dynamics" in K. J. Arrow, M. D. Intriligator (eds) Handbook of Mathematical Economics, vol. 3. Amsterdam: North Holland.

Nikaido, H. (1968) Convex Structures and Economic Theory. New York: Academic Press.

Panek, E. (2003) Ekonomia matematyczna. Poznań: Wydawnictwo Akademii Ekonomicznej w Poznaniu.

Panek, E. (2011) "O pewnej prostej wersji «słabego» twierdzenia o magistrali w modelu von Neumanna". Przeglad Statystyczny 58 (1-2): 75-87.

Panek, E. (2014) "Model gospodarki Gale'a ze zmienną technologią, rosnącą efektywnością produkcji i szczególną postacią kryterium wzrostu. «Słaby» efekt magistrali”. Przeglad Statystyczny 61 (4): 325-34. 
Panek, E. (2015) "A Turnpike Theorem for Non-stationary Gale Economy with Limit Technology. A Particular Case". Economics and Business Review, Vol. 1(15), No 4, 3-13, https://doi.org/10.18559/ebr.2015.4.1.

Panek, E. (2016a) “Gospodarka Gale’a z wieloma magistralami. «Słaby» efekt magistrali”. Przegląd Statystyczny 63 (4): 355-74.

Panek, E. (2016b) “«Silny» efekt magistrali w modelu niestacjonarnej gospodarki Gale’a z graniczną technologią”. Przeglad Statystyczny 63 (2): 109-21.

Panek, E. (2017) “"Słaby» efekt magistrali w niestacjonarnej gospodarce Gale'a z graniczną technologią i wielopasmową magistralą produkcyjną” in D. Appenzeller (ed.) Matematyka i informatyka na ustugach ekonomii. Poznań: Wydawnictwo Uniwersytetu Ekonomicznego w Poznaniu.

Panek, E. (2018) "Niestacjonarna gospodarka Gale'a z graniczną technologią i wielopasmową magistralą produkcyjną. «Słaby», «silny» i «bardzo silny» efekt magistrali”. Przeglad Statystyczny 65 (4): 373-93.

Panek, E. and Runka, H. (2011) "Efekt magistrali w gospodarce Gale'a. Wersja szczególna”. Zeszyty Naukowe Uniwersytetu Ekonomicznego w Poznaniu 211: 220-31.

Panek, E. and Runka, H. (2012) "Dwa twierdzenia o magistrali w modelu von Neumanna". Przeglad Statystyczny 59(2): 125-37.

Radner, R. (1961) "Path of Economic Growth that are Optimal with Regard to Final States: A Turnpike Theorem". Review of Economic Studies 28 (2): 98-104, https://doi. org/10.2307/2295707.

Takayama, A. (1985) Mathematical Economics. Cambridge: Cambridge University Press.

\section{Abstract \\ Niestacjonarna gospodarka Gale’a z graniczną technologią, wielopasmową magistralą i ogólną postacią kryterium wzrostu}

Artykuł nawiązuje do publikacji autora: „«Słaby» efekt magistrali w niestacjonarnej gospodarce Gale’a z graniczną technologią i wielopasmową magistralą produkcyjną" (w: Matematyka i informatyka na ustugach ekonomii, D. Appenzeller (ed.), 2017) oraz „Niestacjonarna gospodarka Gale’a z graniczną technologią i wielopasmową magistralą produkcyjną. «Słaby», «silny» i «bardzo silny» efekt magistrali" (Przeglad Statystyczny 2018, 65 (4)) i zawiera dowód "słabego" oraz „bardzo silnego” twierdzenia o magistrali produkcyjnej w niestacjonarnej gospodarce typu Gale’a z graniczną technologią i wielopasmową magistralą, w której - w odróżnieniu od wskazanych prac - rolę kryterium wzrostu pełni zdyskontowana, addytywna funkcja użyteczności zdefiniowana na wektorach produkcji wytworzonej we wszystkich okresach horyzontu.

Słowa kluczowe: niestacjonarna gospodarka typu Gale’a, graniczna przestrzeń produkcyjna, zdyskontowana użyteczność chwilowa, magistrala wielopasmowa. 